\title{
Corporate sector balance sheets and crisis transmission
}

Christopher Davies

\section{Office for National Statistics}

\section{SUMMARY}

Recent events have had a significant impact on the balance sheets of financial corporations and private non-financial corporations. This article focuses on identifying and measuring current omissions from these balance sheets including activities from the shadow banking system such as hedge funds, structured investment vehicles and private equity. The aim is to improve transparency, making it easier to analyse the transmission of the current financial crisis to these sectors and monitor future developments. the he impact of the recent events upon the market value of assets on financial corporations and private non-financial corporations' (PNFC) balance sheets has been significant. This article focuses on measurement omissions and issues of transparency in the financial and nonfinancial corporation accounts and their importance in transmitting the impacts of the credit crisis.

The Office for National Statistics (ONS) presents these accounts as part of its annual Blue Book publication and they show the stocks and flows of a range of assets and liabilities across institutional sectors. Blue Book data provide extensive detail on the developments in the asset and liability positions of these sectors. Analysis of this data clearly captures one of the most significant causes of the current credit crisis, namely the expansion of banking sector balance sheets.

There are, however, a number of measurement issues relating to the recording of liabilities of both financial corporations and PNFCs. These issues relate directly to non-regulated financial entities, such as special purpose vehicles (SPVs) and hedge funds, which formed part of what has now become known as the 'shadow banking industry?. The main types of activity making up the shadow banking industry are described in the Appendix.

Responsibility for financial stability lies with HM Treasury, the Financial Services Authority (FSA) and the Bank of England. ONS, in addressing these measurement issues is seeking to work in partnership with these bodies to bring about their resolution. At the individual company level, the balance sheets of financial and nonfinancial companies provide us with a snapshot of their financial condition, at any given point in time. Over the recent past however, there has been a lot of attention placed on revenue and earnings, with the possible omission of balance sheet developments. Between 1991 Q1 and 2008 Q1 the UK economy expanded for 64 consecutive quarters. Given this continued period of economic growth the focus of many analysts had drifted towards these output related indicators.

This relative shift in scrutiny from the balance sheet to revenue and earnings was one of the many failures relating to the detection of the credit crisis across countries. The use of off-balance sheet financing by banks for example, through the use of structured investment vehicles (SIVs) and SPVs was in short a sophisticated way of removing liabilities from balance sheets. As such capital could be freed up to continue with further lending and the generation of greater income.

This article discusses the measurement issues relating to the balance sheets of financial corporations and PNFCs and outlines proposals for improving this information, both within ONS and with external stakeholders.

One major issue is that, given the nature of the shadow banking system, a significant amount of activity and accumulation of assets and liabilities is being omitted from the 
financial and non-financial corporations account. To address this, ONS proposes to:

- engage with partners to address the measurement issues around the shadow banking system, including SPVs, hedge funds and private equity

- improve estimates of gross trading profits for fund management and asset finance

- continue work to establish a topto-bottom account for banks which originally started in 2008

- introduce improvements to the liabilities of the bonds line in the Financial Accounts across all sectors and incorporate derivatives data into the National Accounts, and

- develop a coherent approach to asset and liability valuation

\section{Financial corporations and the shadow banking system}

In the National Accounts, the financial corporations sector comprises banks, building societies and non-bank financial institutions. A non-bank financial institution (NBFI), according to National

Accounts definitions, is a financial institution which does not have a full banking license and is neither subject to national or international banking regulation. NBFIs are typically involved in the provision of investment, savings and brokerage activities. Examples include insurance companies and associated brokers and those entities involved in activities such as currency exchange.

The growth in banking sector balance sheets along with measurement omissions and shifting scrutiny all played their part in the development and transmission of today's credit crisis. Such growth in lending would not have been possible without the emergence of what has become known as the shadow banking system. The origin of the term is attributed to Bill Gross, the chief investment officer of Pimco, and relates to 'the whole alphabet soup of levered up non-bank investment conduits, vehicles, and structures'. In plainest terms the shadow banking sector is defined as that part of the financial sector which does not accept deposists and, as such, does not require a license to operate as a bank and consequently is not subject to financial regulation. Shadow banks typically act as intemediaries between investors and borrowers, taking either fees or benefiting from the interest rate spread between what an investor is paid and what is received from a borrower. The high profile entities which comprise the shadow banking system, include hedge funds, SIVs, conduits, money funds, monolines and investment and other non-bank financial institutions. In many cases the sector suffered the consequences of the crisis directly, with the demise of institutions such as Bear Stearns and Lehman Brothers.

The expansion of bank balance sheets in recent years accompanied not only increased indebtedness of non-financial corporations but also that of the household sector, as shown in Figure 1. The considerable size of household debt has been acknowledged as a contributing factor to the ongoing deepening of the crisis.

A further problem is determining the value of assets held by the financial corporations sector since the onset of the credit crisis. Many of the assets generated by entities in the shadow banking system, such as mortgage backed securities, became increasingly difficult to value as the market collapsed. Consequently, uncertainty over the financial strength of commercial banks increased, which in turn placed downward pressure on bank share prices, further increasing the impact of the crisis.

In the absence of reliable market values, there is a danger that balance sheets can be under or over valued at nominal value and could therefore present an incorrect representation of the financial strength of the financial corporations account. Issues of asset and liability valuation are therefore an important measurement area.

\section{Private non-financial corporations}

The measurement omissions relating to sources of finance originating from the shadow banking system also affect the PNFC sector balance sheet, as the counterparty to the financial corporations balance sheet.

Under-recording of the lending of financial corporations will be counterpartied by under-recording of borrowing in other sectors. In addition, there is the issue of the contingent risk posed to the PNFC balance sheet from pensions. For a more detailed account of pensions in the current downturn see the article by Daffin, Levy and Walton (2009) in this edition of Economic and Labour Market Review. With the introduction of new legislation to address the issue of funding gaps, declining equity markets, interest and inflation rates and increasing longevity, the risks around pension liabilities on the PNFC balance sheet are increasing. Measuring and monitoring these risks will continue to pose a challenge.

\section{Funding of PNFCs}

Analysis undertaken internally by ONS (2008) on the financial condition of the PNFC sector explored issues surrounding the measurement of PNFC liabilities. This focused on a number of aspects, beginning with an examination of netlending position and financial account transactions, as shown in Figure 2. This illustrated that in the recent past the sector has been a net lender with existing current and capital expenditure being outstripped by receipts.

The study progressed to examine how the PNFC sector had used its surpluses and deficits to purchase financial assets and liabilities (see Figure 3). What has become clear is that the acquisition of financial assets has generally been in excess of liabilities, confirming that the net acquisition of assets has been funded by the sector's net-lending position as illustrated in Figure 2. Despite this, firms have continued to amass liabilities during

\section{Figure 1}

\section{Accumulation of household total financial liabilities}

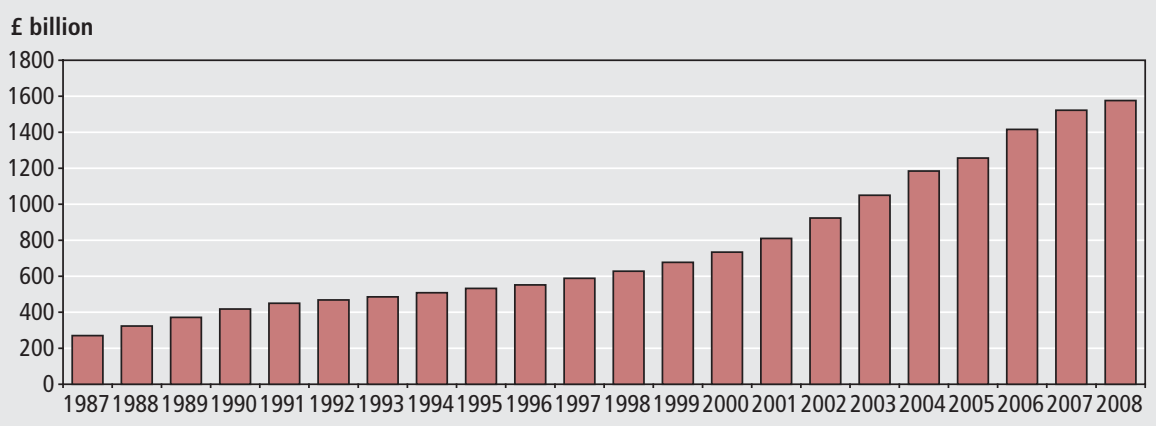




\section{Figure 2}

\section{PNFC net borrowing/lending}

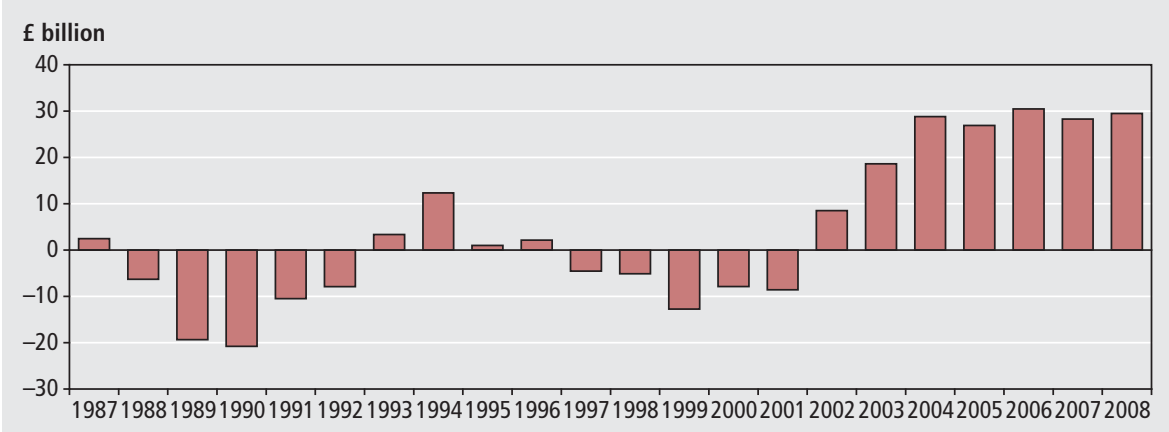

Source: ONS Economic Accounts

\section{Figure 3}

\section{PNFC accumulation of financial assets and liabilities}

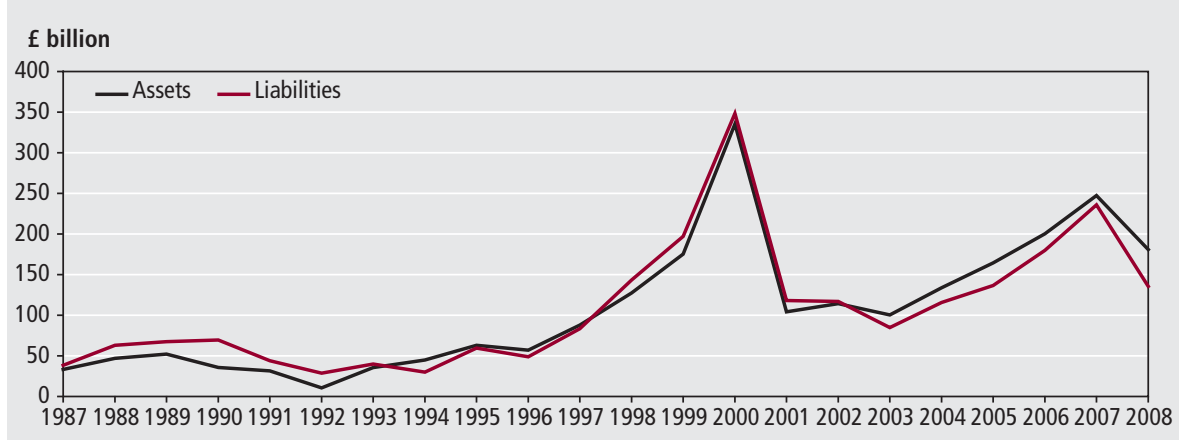

Source: ONS Economic Account

\section{Figure 4}

\section{Short-term sterling loans from UK and rest of the world monetary and financial institutions}

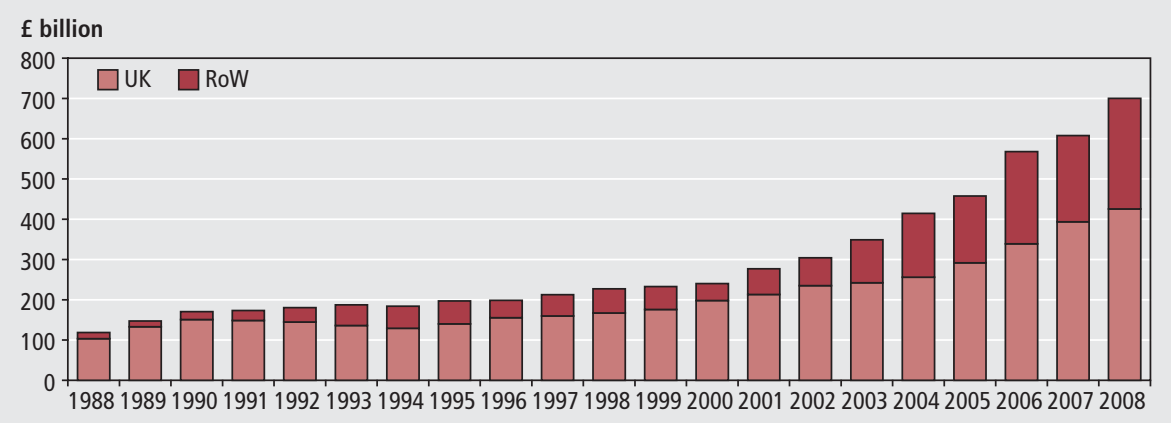

Source: ONS Economic Accounts

\section{Figure 5}

\section{PNFC balance sheet}

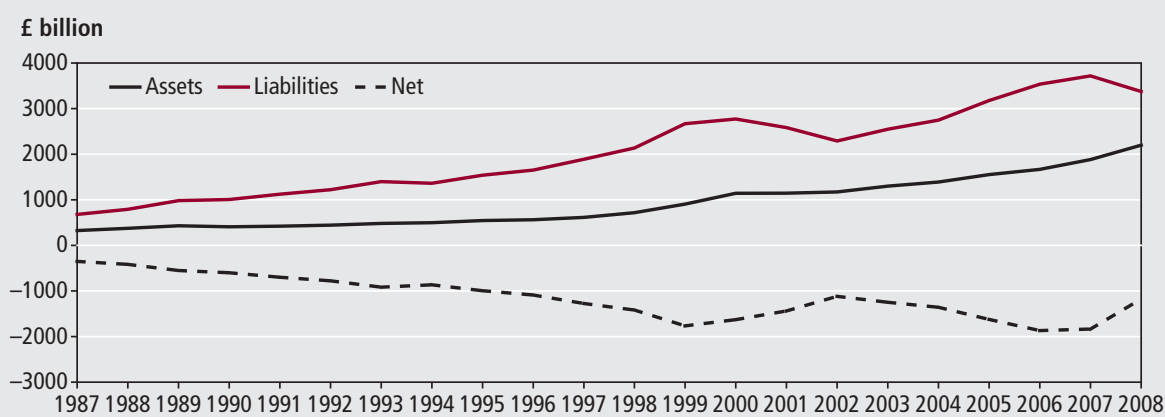

Source: ONS Economic Accounts prosperous periods, with little reduction in their stock of debt. Examining the PNFC balance sheet reveals that at the end of 2007, the accumulation of total liabilities had increased at a faster rate than total assets, to reach a historic high of nearly $£ 3.7$ trillion. As a percentage of Gross Domestic Product (GDP) however, the most recent peak is not as high as that observed following the surge in liabilities following the high growth in equity valuations prior to the stock exchange crash in 2001.

Further analysis on the asset side reveals that firms had built up deposits with UK and rest of world monetary and financial institutions (MFIs), purchased shares and other equity and, particularly in 2005 and 2006, made a number of loans to UK residents.

On the liability side, firms had greatly increased their borrowing from both UK and foreign MFIs as shown in Figure 4. One possible explanation for this could relate to loans sustaining private equity transactions (investment of differing forms, by institutional investors, in operating companies not publicly traded on a stock exchange). This area is difficult to measure however, and is an issue that requires further investigation to obtain a greater understanding of PNFCs liabilities and how gearing/leverage is structured. Another area of PNFC liability funding that requires further investigation is the borrowing connected to the shadow banking system including from hedge funds, private equity and venture capital.

This picture of PNFC liabilities is not complete without considering the total balance sheet position of the PNFC sector as illustrated in Figure 5. It can be seen here that total liabilities have been growing in excess of total assets for some time. Part of this growth can be attributed to the increased borrowing from UK and foreign MFIs as discussed. This however is not the entire story, since the balance sheet position has been further impacted by the growth of unquoted equity, including both foreign direct investment and again private equity. The balance sheet picture is also heavily influenced by price movements and exchange rate fluctuations, which can consequently distort the view of the growth in assets and liabilities on the balance sheet.

In short, analysis of net acquisition of financial assets and liabilities will not result in the balance sheet of the PNFC sector. 


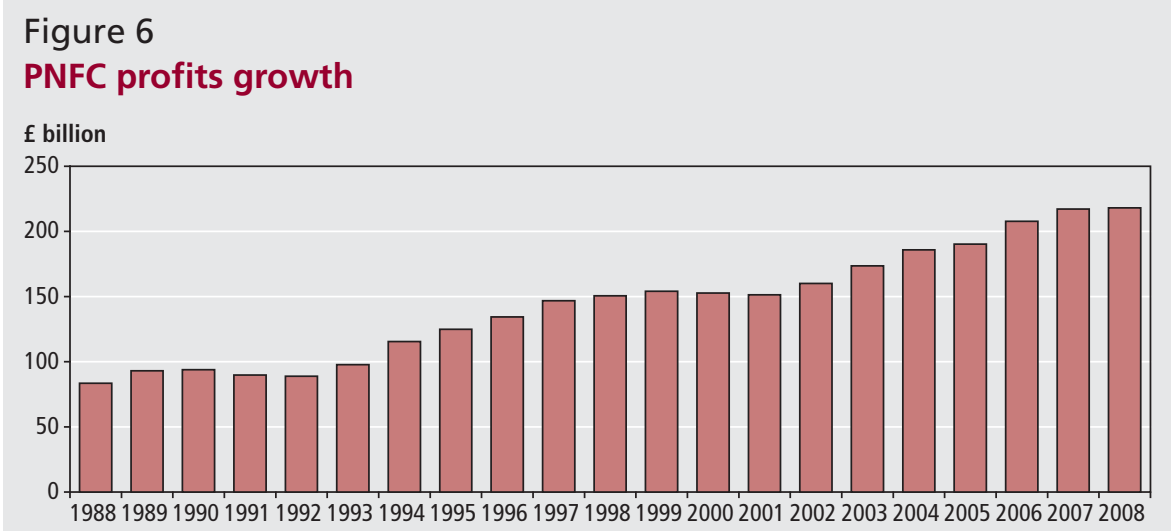

Source: ONS Economic Accounts

Further investigation into PNFC liabilities arising from the shadow banking system, unquoted equity and the influence of price and exchange rate movements will bring us closer to this position.

Notwithstanding other sources of finance therefore, it is clear that the financial health of the sector was perhaps not as strong as might be suggested by the sector's favourable profitability position during the last 20 years (see Figure 6).

An alternative way of examining the liability position of the PNFC sector is via gearing ratios. ONS analysis has examined a range of ratios including:

- debt as a percentage of gross disposable income

- debt as a percentage of GDP

- M4 lending to PNFCs as a percentage of GDP, and

- the income and capital ratios

In general each of these ratios indicated that gearing has increased for the PNFC sector since 2001, whether accounting for equity or not. These ratios, coupled with estimates of omitted liabilities from hedge funds from the Bank of England, reveal a weaker financial position for the sector, prior to the economic crisis, than shown in the National Accounts balance sheets.

ONS' conclusions, coupled with some identified sector account data issues, present two distinct development opportunities for PNFC data analysis. First is to update and share this analysis with stakeholders and second is to work with the same to cover the measurement of omitted liabilities.

\section{Financial corporations accounts}

As a primary step in addressing the measurement issues surrounding the financial corporations account as part of the overall UK National Accounts, ONS has undertaken research into the classification and coverage of financial sector activity, with a view to identifying obvious gaps and addressing how to fill them.

This work looks into the classification of financial corporations and compares UK publications against the international guidelines in the 1993 System of National Accounts (SNA 1993) and the 1995 European System of Accounts (ESA 1995), and in the revised 2008 SNA. These guidelines leave room for the reporting authority to determine the level of reporting detail, according to the complexity of the sector and the needs of the data for policy making, which in the case of the UK are clearly significant. Comparisons between SNA 1993 and SNA 2008 are made against the three major publications which cover financial corporations' activity, these being UK Economic Accounts, the Blue Book and the monthly Financial Statistics.

The research concludes that:

- published UK National Accounts cover a large proportion of financial activity

- they do not provide detailed data at the sub-sector and sub-position level, which would contribute to the resolution of some transparency issues, as well as providing data to map major trends in financial activity. In particular, structured financial products, such as derivatives, private equity and venture capital are not well covered, and

- active coordination with the FSA, Bank of England and HM Treasury, among others, will be essential in meeting these challenges

The full content of the analytical work undertaken will be published in a future edition of Economic and Labour Market Review.

In light of this gap analysis and previous internal reviews of the financial corporations account, a number of key work streams have been identified to improve the quality of the data. This should also lead to better coherence between the income and production measures of gross domestic product (GDP), and more up to date weighting for individual industries within the financial corporations sector. The work will consist of:

- improving estimates of gross trading profits for fund management and asset finance, which are thought to have been underestimated since the cessation of the fund management inquiry in 2000. It is acknowledged that the measurement of asset finance has been limited, given a lack of available resource to ratify data generated via the asset finance inquiry

- updating the weights for the output and gross valued added (GVA) of financial corporations

- continuing development of a top-tobottom account for banks

- improving the validation of finance leasing data

- improving data on bonds liabilities in the financial account across all sectors, and

- incorporating derivatives data into the National Accounts. ONS has already begun to address this and plans to incorporate some derivative data in Blue Book 2010. A review of bonds transactions and holdings is also underway, focusing on the reconciliation of data between the income and capital account and measures in the financial account

ONS runs a series of quarterly surveys collecting financial transactions data from financial corporations (other than banks and building societies) such as insurance companies, pensions funds, investment institutions and securities dealers. There are a number of issues with these surveys, which have been evident for some time including:

- the coverage of the surveys is incomplete

- the data requested are inconsistent, and

- the samples are generally small

As a result, the data are not considered very reliable.

Annual balance sheet data are collected 
via separate surveys, but not from securities dealers. Quarterly balance sheet estimates are estimated from the quarterly flow data. Some investment vehicles such as hedge funds and private equity funds are not covered at all.

The financial balance sheets of PNFCs are covered by a quarterly survey, but collect much more data on assets than liabilities. ONS is developing a strategy to improve the coverage and data quality of all these surveys, making full use of administrative data. The work to develop a new strategy will include:

- investigating new registers to improve survey coverage of the financial sector

- improving reconciliation systems between quarterly and annual data
- assessing the potential for administrative data, especially regulatory data from the FSA

- considering the financial surveys done in other countries (for example Ireland) where balance sheet, flows and revaluation data are collected from reporters together on one quarterly survey form, and

- developing and testing a single survey form to collect financial data from all reporters

\section{Conclusion}

As outlined, ONS will seek to address a number of measurement omissions and data quality issues relating to the financial corporations account internally. There are a number of areas however, where our partners and stakeholders are well positioned, both in terms of data and resource, to assist us with closing the measurement gaps discussed. In particular, ONS would like to engage to address the measurement issues around special purpose vehicles, hedge funds and private equity.

Developing estimates of these activities will be important both in terms of measuring value within the National Accounts and assessing risks relating to both the shadow banking system and the PNFC sector. As well as assessing priority needs, partnership working on these issues will enable capacity and understanding to be created to address future financial innovations, as and when they arise. 


\section{APPENDIX}

\section{The Shadow Banking System}

The main activities include:

\section{Investment banks}

These financial institutions perform a variety of services including, raising capital, acting as an intemediary between an issuer of securities and investors, brokering services for institutional clients and facilitating mergers and corporate reorganisation. Investment banks profit from issuing and selling debt and equity securities in capital markets and insuring bonds on behalf of both the government and companies.

The significant financial strength of the investment banking sector has been profoundly harmed by the onset of the credit crisis. It was the investment bank Bear Stearns, which developed the securitisation and asset backed securities market, which spectacularly collapsed as a large number of sub-prime and subsequently prime mortgage holders began to default on the mortgages which underpinned these tradeable securities. Bear Stearns increasing exposure to this market through 2007 led to its demise in 2008. The resulting contagion amongst other investment banks, coupled with investors witholding their funds, led to the liquidity problems in financial markets which contributed significantly to the onset of the credit crisis.

\section{Hedge funds}

Hedge funds are investment funds which offer their capabilities to wealthy individuals or to professional investors such as insurance companies and pension funds. Hedge funds are a global phenomenon, although the main concentration are in the US. Unlike investment banks and investment management companies, hedge funds are unregulated and consequently are able to adopt far more flexibility in their investment strategies.

Their title suggests that their main purpose is to reduce risk associated with investments, when in fact their main strategy is to maximise returns on the investments that they make and manage. As a class of investments, each fund has its own investement strategy and can choose from a wide range of investments, including shares, debt and commodites. Hedge funds contributed significantly to the transmission of the credit crisis, through what has now become a well known term of 'short-selling' both the shares of investment and commercial banks, thereby reducing their ability to raise capital in the face of increasing defaults. This intervention on the part of hedge funds was another factor pushing for government involvement in recapitalising the banking sector.

\section{Structured investment vehicles (SIVs)}

These funds were made up of a pool of investments that attempted to make profits from the credit spreads between short-term debt and long-term structured finance products such as assetbacked securities. The funding of these vehicles came from the issuance of commercial paper that is continually rolled over and the proceeds are used to purchase long dated illiquid assets with higher returns. Plainly, the returns gained from the longer dated assets, typically the principal and interest payments from asset backed securities (for example mortgages to purchase homes) exceeded the cost of raising funds to invest in these securities, usually higher-rated commercial paper. SIVs were usually large in size ranging from $\$ 1$ billion to $\$ 30$ billion and invested in a a range of asset backed securities including financial corporate bonds.

Typically SIVs were operated by commercial banks and investment houses and were generally held off balance sheet, thereby allowing them to operate outside of regulation. Essentially SIVs allowed the managing financial institutions to use leverage in a way that the parent company would not have been able to do because of capital requirement regulations. The onset of the credit crisis wiped significant proportions off the value of the balance sheets of SIVs with obvious consequences for investors (banks and investment houses) in these vehicles. As of October 2008, as a result of the impact of the credit crisis on the increased default rates amongst asset backed securities these funds ceased to exist. SIVs are also known as conduits.

\section{Money market funds}

Money market funds, or principal stability funds, are investment funds that invest solely in cash or cash equivalents. Cash equivalents are high credit quality short-term investments that are easy to buy and sell and are usually comprised of government bonds and commercial paper. The credit crunch impacted on these funds markedly as many funds also invested in mortgage backed securities and floating rate notes, both of which have tumbled in value. Investors usually choose to invest in these funds to avoid market volatility. Individuals often choose to shift their pension funds into money market funds as they approach retirement. 


\section{Monolines}

Monolines, so called because the service is provided to only one industry, provides insurance cover against the risk that a bond will default. During the recent boom, both governments and private companies took the opportunity of paying a fee to have the bonds they issued parcelled up into top-grade credit rated investments. This allowed the issuers the opportunity to raise funds more cheaply, since the credit rating offered on parcelled up investments was in excess of that of the single issuance. Recent estimates suggest that at the peak of the boom, the top monoline insurers guaranteed approximately $\$ 2.4$ trillion of bonds.

Over the last ten years many insurers expanded their portolios from government and private company bonds into collaterlised debt obligations (CDOs), which contained sub-prime mortgages. With the impact of the credit crisis, monoline insurers have been hit from all sides. Firstly, the value of CDO's have been written down sharply, as defaults amongst sub-prime components have increased. This has led to a slump in the share value of monoline insurers, whom it is feared have insufficient capital to pay holders of failed bonds. Rating agencies have subsequently asked monoline insurers to hold more capital in the face of increasing defaults, but with share values falling this has become increasingly difficult.

\section{Private Equity}

Since the beginning of this decade the markets for private equity (leveraged buyouts, venture capital, growth capital, distressed investments and mezzanine capital) have grown strongly. These asset classes, consisting of equity securities in existing businesses are not quoted on the stock exchange. Consequently, there has been a clear difficulty in measuring the funding structure of PNFCs, which will have added to the mis-representation of the strength of the sector to policymakers discussed in the main body of this paper. 